\title{
УДК 355.58
}

\section{ФОРМИРОВАНИЕ БЕЗОПАСНОГО ПОВЕДЕНИЯ У УЧАЩИХСЯ В СЛУЧАЕ ВООРУЖЕННОГО НАПАДЕНИЯ НА ОБРАЗОВАТЕЛЬНУЮ ОРГАНИЗАЦИЮ}

\section{Бабичев Арсентий Юрьевич}

Балашовский институт (филиал) ФГБОУ ВО «Саратовский национальный исследовательский государственный университет имени Н.Г.Чернышевского»

Аннотация: В статье рассматриваются причины вооруженных нападений нынешних или бывших учащихся на образовательную организацию, приводящих к гибели или ранению педагогов, обучающихся, рабочего персонала. Подчеркивается необходимость формирования у учащихся навыков безопасного поведения при скулшутинге. В работе приводятся результаты анкетирования, свидетельствующие о том, что $40 \%$ респондентов не готовы применить правила безопасного поведения в подобных ситуациях. Поэтому в статье предлагается программа, включающая ряд мероприятий, направленных на формирование готовности у учащихся к применению правил безопасного поведения в случае вооруженного нападения на образовательную организацию

Ключевые слова: учащиеся, образовательная организация, вооруженное нападение, скулшутинг, безопасное поведение.

\section{DEVELOPMENT OF SAFE BEHAVIOR IN STUDENTS IN CASE OF AN ARMED ATTACK ON EDICATIONAL ESTABLISHMENTS}

\section{Babichev Arsenty Yurievich}

\begin{abstract}
: the paper deals with the reasons of armed attacks of current and former students on educational establishments, causing deaths or injuries of teachers, students and staff. The necessity of developing safe behavior skills of students in situations of schoolshooting is pointed out. The paper includes questionnarie results showing that 40 per cent of students are not ready to apply rules of safe behavior in such situations. That'why we offer the program that comprises a set of events aimed
\end{abstract}


at developing student readiness to apply the rules of safe behavior in situations of armed attacks on educational establishments.

Key words: students, educational establishment, armed attack, schoolshooting, safe behavior.

Актуальность исследования. В последние годы резко увеличилось количество вооруженных нападений на образовательные организации, совершаемых нынешними или бывшими учащимися данного учебного заведения. Пострадавшими становятся педагоги, обучающиеся и рабочий персонал. Такие нападения предполагают применение насилия на территории учебного заведения (в основном против учащихся) и часто приводят к массовым убийствам. В США, где для совершения нападений чаще всего используется огнестрельное оружие, это явление называют стрельбой школьников или стрельбой в школах (англ. schoolshooting) [1]..

Основная масса подобных нападений зарегистрирована в США, меньше в странах Европы. В России зафиксировано около 20 случаев скулшутинга, начиная с 2014 года, и совершены эти нападения на учащихся в основном с использованием холодного оружия, потому что нож ребенку легче достать, чем огнестрельное оружие [2, с.63].

Поэтому целью нашего исследования стало выявление степени осведомленности обучающихся о правилах безопасного поведения в случае вооруженного нападения и поиск путей совершенствования профилактики агрессии и насилия в образовательной организации.

Объект исследования - учебно-воспитательный процесс в образовательной организации.

Предмет исследования - процесс формирования безопасного поведения обучающихся при скулшутинге в образовательных организациях.

Meтоды исследования: анализ, синтез и обобщение данных педагогической, научной, методической литературы по проблеме исследования; планирование и разработка программы исследования; анкетирование; количественный и качественный анализ результатов исследования; математикостатистические методы обработки полученных данных.

Результаты исследования. Анализ педагогической и психологической литературы по теме исследования показал, что большинство подростков заранее готовили нападение на педагогов и учащихся. В некоторых случаях даже предупреждали одноклассников о предстоящем событие. Однако, никто 
не обратил внимание на странности в поведении подростков до того, как произошла трагедия. Зато после нападения и одноклассники, и педагоги, и родители в беседе со следователем рассказывали об особенностях психики нападавшего в последнее время, о конфликтах, о травле его и т.д.

На основе результатов анализа полученных данных по проблеме профилактики вооруженного нападения в образовательной организации мы выяснили, что научных исследований в данной области крайне мало. В основном все работы посвящены действиям человека в случае захвата заложников террористическими группами или одним человеком. Что касается действий в случае нападений учащимися образовательных учреждений на своих одноклассников или преподавателей, то таких рекомендаций и мероприятий практически нет. Имеющиеся публикации посвящены, в основном, изучению причин и последствий нападений в образовательных организациях. Кроме этого не разработаны и методические рекомендации по профилактике вооруженных нападений для участников образовательного процесса и правила поведения при таких ситуациях.

Как оказалось, изначально образовательные организации не были готовы к решению данной проблемы, но со временем стала проводиться работа по профилактике жестокого обращения с детьми и формированию у учащихся и педагогов безопасного поведения в случае скулшутинга.

Во время прохождения педагогической практики на базе Муниципального образовательного учреждения «Средняя общеобразовательная школа № 9 имени П.А. Столыпина г. Балашова Саратовской области» нами были проанализированы мероприятия по данной проблеме, проводимые школой. Установлено, что школа проводит большую работу по профилактике скулшутинга. Безопасность школы является приоритетной в деятельности администрации и педагогического коллектива. Поэтому в целях обеспечения безопасного режима функционирования школы, создания необходимых условий для проведения учебно-воспитательного процесса, охраны жизни и здоровья детей в 2019/2020 учебном году проводилась целенаправленная работа, в том числе и организация антитеррористической защищенности, по взаимодействию с родителями и воспитанниками, правоохранительными органами и структурами.

Для выявления информированности обучающихся о безопасном поведении в случае вооруженного нападения нами была разработана анкета, включающая 10 вопросов. 
1. Слышали ли Вы когда-нибудь о вооруженных нападениях в образовательных организациях?

2. Встречались ли Вы с таким явлением?

3. О каких случаях вооруженного нападения на образовательную организацию Вы знаете?

4. Как Вы считаете, почему учащиеся совершают вооруженные нападения на учителей, учащихся?

5. Как Вы считаете, можно ли предупредить вооруженное нападение на образовательную организацию?

6. Проводят ли с вами беседы о правилах поведения при вооруженном нападении на образовательную организацию?

7. Считаете ли Вы, что тема вооруженного нападения на образовательную организацию является актуальной и ей нужно больше уделять внимания?

8. Знаете ли вы правила безопасного поведения в случае вооруженного нападения?

9. Готовы ли Вы придерживаться правил безопасного поведения для учащихся и педагогов в случае вооруженного нападения?

10 Готовы ли Вы принимать участие в проведении различных мероприятий по формированию навыков безопасного поведения в случае вооруженного нападения на образовательную организацию?

Респондентами выступили учащиеся 8-9 классов в количестве 20 человек. Результаты анкетирования показали, что все обучающиеся слышали о вооруженных нападениях на образовательные организации, но встречаться с таким явлением им, к счастью, не приходилось. Отвечая на третий вопрос, 80 \% респондентов назвали случай в Политехническом колледже в г. Керчь, а $20 \%$ вспомнили вооруженное нападение на школу № 127 в г. Пермь. Все учащиеся считают, что наиболее распространёнными причинами нападения обучающимися на образовательные учреждения являются нарушение психического здоровья, проблемы в семье и жестокое обращение со стороны одноклассников и педагогов, травля в школе. Менее распространённой причиной стало пагубное влияние Интернета, особенно компьютерных игрстрелялок. Отвечая на вопрос: «Как Вы считаете, можно ли предупредить вооруженное нападение на образовательную организацию?», мнения респондентов разделились. Большинство учащихся (60\%), считают, что это невозможно, 20 \% полагают, что если бы кто-то вовремя обратил внимание на 
ребенка, пытающегося докричаться до взрослых, то не было бы жертв и сломанных судеб, остальные (20 \%) затруднились ответить. На шестой и седьмой вопросы все ответили утвердительно. Ответы учащихся на восьмой вопрос свидетельствуют о том, что они хорошо осведомлены о правилах поведения в случае вооруженного нападения на образовательную организацию, но не допускают мысли, что это может сделать кто-то из учащихся данного учебного заведения. Также они отметили, что чаще всего это информация о правилах поведения при захвате здания террористами, которые совершают такое деяние с определенной целью и выдвигают ряд требований.

Однако на вопрос: «Готовы ли Вы придерживаться правил безопасного поведения для учащихся и педагогов в случае |вооруженного нападения?» утвердительно ответили 60 \%. Остальные ответили, что не готовы. На вопрос: «Готовы ли Вы принимать участие в проведении различных мероприятий по формированию навыков безопасного поведения в случае вооруженного нападения на образовательную организацию?» 100 \% респондентов ответили утвердительно.

На основании полученных данных нами была разработана и частично апробирована программа «Безопасное поведение учащихся в случае вооруженного нападении на образовательную организацию», включающая целевой, организационный, содержательный и диагностический компоненты.

Целевой компонент включает цель - совершенствовать систему воспитания у обучающихся ответственности за свою жизнь и умения грамотно действовать в случаях скулшутинга и задачи: 1) выработать интерес к самостоятельному получению знаний о безопасном поведении в случае скулшутинга; 2) развить способность к осмыслению прогностических критериев готовности учащихся к насилию; 3) научить прогнозированию последствий скулшутинга.

Организационный компонент включает создание учебного пространства, располагающего к взаимодействию учителя и учащегося, мотивации участников образовательного процесса к сотрудничеству. При реализации организационного компонента планируется проведение классного часа «Причины вооруженных нападений учащихся на образовательную организацию», круглого стола «Профилактика вооруженного нападения обучающихся в образовательных организациях» и тренинга «Как правильно себя вести при скулшутинге». 
В содержательный компонент входит отбор и структурирование материала по теме классного часа «Причины вооруженных нападений учащихся на образовательную организацию», круглого стола «Профилактика вооруженного нападения обучающихся в образовательных организациях» и тренинга «Как правильно себя вести при скулшутинге», составление творческих ситуаций, тестовых заданий и викторины, рабочей программы и фонда оценочных средств.

\section{Диагностический компонент содержит}

инструментарий, включающий различные методики на выявление осведомленности учащихся о причинах скулшутинга, правилах безопасного поведения и их готовности применять эти правила на практике в случае вооруженного нападения.

Таким образом, вооруженные нападения учащихся на образовательные организации происходят все чаще и чаще в различных уголках нашей страны и становятся актуальной проблемой обеспечения безопасности учащихся.

Результаты нашего исследования показали, что у обучающихся сформированы представления о безопасном поведении в случае вооруженного нападения, благодаря проведению специально организованных мероприятий. Однако, имея хорошие теоретические знания, 40 \% учащихся не уверены, что смогут реализовать их на практике в случае скулшутинга. Поэтому необходимо продолжать обучать учащихся безопасному поведению в случае вооруженного нападения в стенах образовательной организации, используя инновационные технологии.

\section{Список литературы}

1. Скулшутинг и «Колумбайн» по-русски [Электронный ресурс] // Режим доступа: https://www.ya-roditel.ru/parents/base/experts/skulshuting-i-kolumbaynpo-russki/

2. Давыдов Д.Г., Хломов К.Д. Массовые убийства в образовательных учреждениях: механизмы, причины, профилактика // Национальный психологический журнал. - 2018. - № 4 (32). - С. 62-76.

(C) А.Ю. Бабичев, 2020 